\title{
A Indicação de Procedência como instrumento de diferenciação: o caso do Doce de Pelotas
}

\author{
The Indication of Origin as a mechanism of differentiation: the \\ case of Pelotas' Candy
}

\author{
Patricia Pereira Peralta \\ Instituto Nacional da Propriedade Industrial - Rio de Janeiro - RJ - Brasil \\ Mônica Christina Rodrigues Morgado \\ Instituto Nacional da Propriedade Industrial - Rio de Janeiro - RJ - Brasil \\ Elizabeth Ferreira da Silva \\ Instituto Nacional da Propriedade Industrial - Rio de Janeiro - RJ - Brasil \\ Dirceu Yoshikazu Teruya \\ Instituto Nacional da Propriedade Industrial - Rio de Janeiro - RJ - Brasil
}

\begin{abstract}
Resumo: A competitividade dos produtos agroindustriais baseia-se na diminuição de custos e na necessidade de diferenciação. Essa diferenciação de produtos pode se dar por meio da indicação geográfica, cujo registro confere aos membros aptos a utilizar a designação geográfica, decorrente da reputação e da fama de um determinado produto manufaturado oriundo dessa região, com exclusividade. Os produtores de doces na região de Pelotas se organizaram e obtiveram o registro de indicação geográfica no Instituto Nacional da Propriedade Industrial - INPI, embora esses produtores ainda estejam aperfeiçoando o processo de uso desse instrumento como vantagem competitiva.

Palavras chaves: Indicações Geográficas. Doces de Pelotas. Diferenciação.
\end{abstract}

Abstract: The agro-industrial activities present their competitiveness of products based on cost reduction and the need for differentiation. One of the mechanisms of product differentiation is a Geographical Indication, which allows the applicant of its register, from a geographical designation, due to the reputation and fame of a particular product manufactured in this region. Producers of candies in the region of Pelotas have organized and obtained the register of Geographical Indication at the National Institute of Industrial Property (INPI), but these producers are improving the process of use this mechanism as a competitive advantage.

Keywords: Geographical Indications. Pelotas' Candy. Differentiation.

\section{Introdução}

A competitividade nos setores agroindustriais e de produtos agrícolas como o de produtos alimentícios baseia-se em custos e na busca da diferenciação de produto para agregar valor. A estrutura de mercado desses setores é concentrada em grandes produtores, decorrente da capacidade de promoção de economias de escala e de escopo. Ao mesmo tempo, esses setores apresentam um conjunto de pequenos e 
médios produtores que detêm um raio de atuação restrita, em função da limitação dos canais de distribuição, marketing e logística.

Um possível instrumento de diferenciação de produto nos setores agroindustriais e agrícolas é a indicação geográfica - IG. Trata-se de um direito de propriedade industrial que confere a seu titular o direito ao uso exclusivo de uma designação de região, localidade, pela sua fama ou reputação dos produtos oriundos daquela (GONÇALVES, 2007, p. 59). A IG vem se tornando um elemento de relevância nos mercados locais, regionais e mesmo no internacional.

Produtos que ostentam indicações geográficas apresentam uma possibilidade de agregação de valor e melhor aceitação por mercados consumidores mais especializados, uma vez que não estão competindo por custo, e sim por diferenciação.

Os nomes geográficos podem ser tutelados através das IGs, que identificam localidades que se tornaram conhecidas como centro de produção, extração, prestação ou fabricação de determinado produto ou serviço ou, ainda, aquelas cujos produtos detenham certa reputação ou determinadas características derivadas do meio geográfico e que passam a ser aceitos e consumidos exatamente por esses diferenciais.

O objetivo deste trabalho será discutir o processo de reconhecimento da indicação de procedência para os doces de Pelotas. A metodologia deste trabalho será um estudo de caso do processo de reconhecimento de indicação de procedência do Doce de Pelotas, a partir da revisão da literatura e da reflexão sobre o setor agroalimentar e a IG e da análise da documentação encaminhada ao INPI para fins de reconhecimento do nome geográfico como um direito propriedade industrial. $O$ acesso aos autos do processo de reconhecimento mencionado foi essencial para atender aos objetivos do artigo ora apresentado, na medida em que possui relevantes informações sobre os mais variados aspectos.

A própria disposição dessas informações pelo requerente Associação dos Produtores de Doces de Pelotas auxiliou os pesquisadores a promover recortes metodológicos que possibilitaram a análise da documentação, como: o espaço geográfico, informações históricas e socioeconômicas, caracterização de agentes locais etc.

A partir da didática divisão empreendida pelo requerente acima citado na documentação encaminhada para instrução técnica do processo, os pesquisadores puderam efetuar uma taxonomia que auxiliou na análise e cruzamento das informações contidas no processo da indicação geográfica com outras pesquisas e dados disponibilizados em artigos acadêmicos e material informativo. Portanto, o grande norteador teórico e metodológico da pesquisa foi o próprio processo administrativo de reivindicação do reconhecimento da IG.

Com o fito de dar conta do objetivo deste artigo, num primeiro tópico, apresentar-se-ão algumas especificidades atuais do mercado agroalimentar que vem se caracterizando por um movimento de busca de qualidade e do uso de sinais que informem sobre as características e especificidades dos produtos a serem consumidos. Como disposto por Nierdele (2013, p. 30), “[...] ao longo das últimas cinco décadas o 
setor agroalimentar presenciou uma mudança substancial na percepção dos produtores e consumidores em relação à qualidade".

$\mathrm{Na}$ segunda parte, abordar-se-á a IG, procurando definir essa figura, bem como o escopo legal da proteção. Num terceiro momento, procurar-se-á caracterizar a produção de doces na região de Pelotas, resgatando, por meio da literatura disponível sobre o tema, informações que auxiliem na compreensão das especificidades dessa produção. Em seguida, e como objetivo principal deste artigo, analisar-se-á o processo de requerimento da IG de Pelotas, que possibilitou a concessão da proteção legal desse nome geográfico, conforme o mesmo se encontra depositado junto ao INPI. Por fim, serão tecidas algumas conclusões sobre a análise a ser empreendida.

\section{0 uso de sinais distintivos de "Qualidade" no mercado agroalimentar}

Os produtos e serviços disponíveis no mercado pretender atender às necessidades e anseios dos consumidores. Estes se dispõem a pagar até um determinado nível de preço para aquisição de um produto ou serviço. No entanto, bens homogêneos são facilmente encontrados no mercado, por conta de uma grande quantidade de ofertantes. Nesse sentido, os agentes buscam redução de custos para competir no mercado. As margens de lucros tendem a ser relativamente menores, o que pode não incentivar a permanência de produtores no segmento em que atuam, no médio e longo prazos, em face do custo de oportunidade de ganhos em outros setores.

Cabe destacar que a produção agrícola e agroindustrial teve um aumento de produtividade e eficiência, quer seja pelo desenvolvimento de sementes, quer seja pelo desenvolvimento de maquinário, quer seja pela interação dos elos da cadeia produtiva (FARINA e ZYLBERSTAJN, 1991).

Outro ponto é a estruturação em complexos agroindustriais e dos elementos de cada parte da cadeia produtiva para gerar economias de escala e de escopo. Isso resultou na constituição de grandes conglomerados produtivos, que atuam em dimensão internacional (WILKINSON, 1996 e 2003).

Esses grandes conglomerados, que atuam em diferentes elos da cadeia produtiva, apresentam significativa concentração no mercado internacional. Por isso, tem-se nas últimas duas décadas, um aumento de fusões e aquisições para incorporar a tecnologia, uma otimização dos canais de distribuição e acesso a novos mercados à estrutura existente dos conglomerados.

Em contrapartida, os agentes em setores de produtos homogêneos buscam a diferenciação de produtos para uma demanda qualificada. A incorporação da diferenciação de produto pode representar um custo de produção relativamente maior, embora também seja relativamente maior a expectativa de retorno de receita.

Ao mesmo tempo, os pequenos e médios produtores têm limitação de atuação no mercado concentrado, pois esses não conseguem ter um desempenho semelhante em termos de produtividade, de acesso aos canais de distribuição dos produtos agrícolas e agroindustriais e de competição em mercados baseados em custos. 
O mercado de consumo de alimentos tem passado por significativas transformações em função da busca do aumento de renda da população e por padrões de qualidade mais confiáveis por parte do consumidor. Essas transformações têm impacto em toda a cadeia produtiva de alimentos. Para Canever et.al (2004), os avanços tecnológicos e organizacionais também auxiliaram na alteração da fisionomia do agronegócio, tornando as economias e os mercados não apenas meros supridores, mas orientados pela demanda dos consumidores. Segundo os autores, esse atendimento às demandas do consumidor e a maior proximidade entre os produtores e consumidores tornaram-se trunfos competitivos imprescindíveis para as atividades de produção (CANEVER et.al, 2004, p.5). Para Cerdan (2013):

[...] os sistemas agroalimentares são, atualmente, caracterizados por um duplo processo: 1) a padronização de produtos e modos de produção, livre circulação e grande escala de produção, em uma economia globalizada e 2) a valorização de produtos de qualidade buscando responder às incertezas crescentes dos consumidores urbanos e estabelecer estratégias de diferenciação em mercados cada vez mais concorrentes." (CERDAN, 2013, p. 126).

A qualidade, as características específicas presentes em certos produtos e a possibilidade de rastreabilidade da produção passaram a ser importantes informações para os consumidores. De forma a conseguir comunicar esses tipos de informações e especificidades dos produtos, sinais distintivos passaram a ser utilizados, como são os casos das IGs, objeto deste artigo, as marcas coletivas e as marcas de certificação. $O$ uso desses sinais é associado a outras formas de aferir, controlar e vigiar os padrões que passam a ser almejados pelos agentes na atual realidade do mercado alimentar.

Como reflexos das transformações tecnológicas e da configuração do tecido agrícola e agroindustrial brasileiro, busca-se a diferenciação dos produtos agrícolas e agroindustriais, principalmente para organizações de pequenos e médios produtores rurais e sócio empresários participantes da cadeia agroindustrial (VITROLLES, 2013).

Em mercados segmentados, como o caso de produtos agrícolas ou agroindustriais, a criação de elemento de reputação está relacionada à redução de assimetria da informação. A indicação geográfica é um dos instrumentos para atenuar essa assimetria e possibilitar a apropriabilidade (BELLETTI et al, 2015a, b). De forma a compreender o que venha a ser esse sinal, no próximo tópico, será discutido o escopo do instrumento de IG como possibilidade de diferenciação, de agregação de valor e de apropriabilidade ao produto agroindustrial.

\section{Indicação geográfica: definições e escopo da proteção legal}

A IG é um direito de propriedade industrial relacionado à reputação de um bem oriundo de um lugar geográfico ou de um bem que possua características específicas essencialmente em função do meio geográfico no qual o mesmo se originou. 
A evolução da noção de IG possui uma trajetória maior no plano internacional e, praticamente, inexistente no plano nacional. A primeira proteção para uma IG foi para a região do Porto, reconhecida produtora de um vinho com características específicas. Cerdan (2013), analisando o surgimento da noção de IG, aponta:

\begin{abstract}
cabe lembrar que a noção de indicação geográfica surgiu de forma gradativa, quando produtores e consumidores passaram a perceber os sabores ou qualidades peculiares de alguns produtos que provinham de determinados locais. Ou seja, qualidades - nem melhores nem piores, mais típicas, diferenciadas - jamais encontradas em produtos equivalentes feitos em outro local. Assim, começou-se a denominar os produtos - que apresentavam essa notoriedade - com o nome geográfico de sua procedência. Os vinhos foram os primeiros nos quais se observou a influência, sobretudo, dos fatores ambientais (clima, solo, relevo etc.)." (CERDAN, 2013, p. 127).
\end{abstract}

No plano internacional, a Convenção da União de Paris para a Proteção da Propriedade Industrial de 1883, doravante CUP, foi o primeiro instrumento internacional a estabelecer princípios básicos de propriedade industrial. Nela está prevista a proteção de direitos industriais como as marcas, as patentes e os desenhos industriais. As IGs não foram inseridas nessa Convenção, onde apenas era encontrada uma proteção, de conteúdo negativo, expressa pelo combate às falsas indicações de procedência.

Apenas com o Acordo de Lisboa, já no século $X X$, foi estabelecido o marco legal da denominação origem, no plano internacional. Esse Acordo foi assinado por um número relativamente pequeno de países, tendo em vista o pouco interesse que a maioria dos países demonstrava pelo reconhecimento desse direito.

Apenas com o advento do Acordo sobre Aspectos dos Direitos de Propriedade Intelectual Relacionados ao Comércio - TRIPS ou ADPIC ${ }^{1}$, a proteção às indicações geográficas passou a ser obrigatória nas legislações de propriedade intelectual dos países membros da Organização Mundial do Comércio - OMC. Conforme consta no texto de TRIPS:

indicações geográficas são, para os efeitos deste Acordo, indicações que identifiquem um produto como originário do território de um Membro, ou região ou localidade deste território, quando determinada qualidade, reputação ou outra característica do produto seja essencialmente atribuída à sua origem geográfica.

A partir desta definição, vários países internalizaram conceitos de IGs em suas legislações, como foi o caso do Brasil. TRIPS estabelece um padrão mínimo de proteção que deve ser, compulsoriamente, observado pelos países membros. Por isso, como pode ser observado no texto de TRIPS, não existe uma definição de

\footnotetext{
1 Esse acordo é um anexo do Acordo de Marrackesh relativo às negociações ocorridas no âmbito da Rodada Uruguai entre 1986 e 1994 no âmbito do Acordo Geral de Tarifas e Comércio (GATT). A partir de então, tem-se o surgimento da Organização Mundial do Comércio para regular as temáticas relacionadas ao comércio negociadas no âmbito desse acordo.
} 
denominação de origem, acompanhando o Acordo de Lisboa, e, sim, uma conceituação mais geral da categoria IG. Essa categorização mais geral permitiu aos países optarem por proteger as IGs pela informação sobre a proveniência do produto ou serviço (ALMEIDA, 1999, p.66) pela reputação, pelas características intrínsecas fornecidas pelo terroir ${ }^{2}$ ao produto (denominações de origem), ou, ainda, pelas duas últimas, como ocorre no Brasil.

Mediante tais colocações, faz-se oportuno analisar os apontamentos realizados por Cerdan (2013) sobre o conceito de IGs:

[...] o conceito de indicação geográfica valoriza particularidades de diferentes produtos de diferentes regiões, cria um fator diferenciador para produto e território, que apresentam originalidade e características próprias. Afinal, as indicações geográficas não diferenciam somente os produtos ou serviços, mas também os territórios." (CERDAN, 2013, p. 127).

Na citação de Cerdan (2013), observa-se que há estreita ligação entre o produto ou o serviço e o território, o que, no Brasil, é atribuído a uma das espécies de IGs e não a todo o gênero. Isso porque só as denominações de origem servem para designar produto ou serviço que, conforme Gonçalves (2007, p.57), tenha " [...] necessariamente qualidade ou características peculiares" que se devem essencial ou exclusivamente ao meio geográfico, compreendendo os fatores naturais e humanos.

De acordo com Almeida (1999, p. 58), os produtos ou serviços que ostentam uma denominação de origem são originários da área delimitada e, para serem considerados típicos, devem ser originários dessa área "[...] e reunir determinadas qualidades e características próprias que não se encontram em qualquer outro local. A origem geográfica é determinante para a qualidade e as características do produto; produto diferente dos que procedem de outros lugares, e isto, devido [à]s condições naturais de produção, ligadas ao meio geográfico físico, como o solo, o subsolo, o clima, etc., e devido ao meio humano que utiliza certos processos técnicos e conhece certas tradições."

Já as indicações de procedência são "[...] uma simples informação, relativa [à] proveniência de um produto, destinada ao público consumidor. Indica simplesmente o lugar de fabrico, elaboração ou extracção do produto". Ela "[...] não garante, por conseguinte, ao consumidor certa qualidade ou determinadas características dos produtos devidas exclusiva ou essencialmente ao meio geográfico, como o faz a DO." (ALMEIDA, 1999, p. 66). Como dito por Gonçalves, "[...] a indicação de procedência apenas situa o produto. Basta ser tal região ou localidade conhecida como referência de centro ou polo de produto ou prestação de serviço" (GONÇALVES, 2007, p. 56).

As IGs são compreendidas numa categoria mais genérica, denominada de sinais distintivos do comércio. Essa denominação refere-se ao fato de a IG identificar e diferenciar produtos e serviços de determinada localidade de outros análogos. Mais

\footnotetext{
2 "A palavra terroir passa a exprimir a interação entre o meio natural e os fatores humanos. E esse é um dos aspectos essenciais do terroir, de não abranger somente aspectos do meio natural (clima, solo, relevo), mas também, de forma simultânea, os fatores humanos da produção - incluindo a escolha das variedades, aspectos agronômicos e aspectos de elaboração dos produtos." (TONIETTO, 2007, p. 1).
} 
que isso, tais sinais distintivos se encontram no mercado, ou seja, no comércio, informando ao consumidor a origem e, dependendo da espécie, as características do produto por eles assinalado.

As IGs passaram a ser um sinal distintivo com capacidade de agregação de valor na medida em que, eventualmente, fornecem informações sobre o produto. Dessa forma, tais sinais passaram a permitir maior aceitabilidade dos produtos em mercados de países desenvolvidos, bem como permitiram aos produtores explorarem sua produção, distribuindo-a por um preço diferenciado. Como uma estratégia de inserção no mercado, as IGs possibilitam aos produtores entrarem em nichos específicos de consumo, onde consumidores mais especializados se dispõem até a pagar mais por produtos assinalados por sinais que transmitem informações e valores apreciados pelos mesmos.

Nesse sentido, oportuno observar Gonçalves (2007, p. 241-2), segundo o qual, "[...] a competitividade no mercado exige uma diferenciação do produto ou serviço que constitui o meio de resistência essencial para a sua subsistência, crescimento e sucesso econômico. Se a identidade do produto é forte, a substituição por outro é reduzida, a concorrência menos agressiva, a concorrência pelos preços menos ativa". Dá-se isso porque o uso da IG permite a identificação de atributos e características relacionadas à origem geográfica capaz de servir como estratégia mercadológica.

No Brasil, só com a promulgação da Lei 9279/1996, Lei da Propriedade Industrial - LPI, que incorporou as disposições do TRIPS/ADPIC, pôde-se instituir proteção legal das IGs, por meio de registro próprio.

Segundo o artigo 176 da LPI, constitui IG a indicação de procedência ou a denominação de origem (BRASIL, 1996). Ou seja, no caso do Brasil, IG é um gênero que comporta duas espécies. O legislador brasileiro inovou, por meio da LPI, ao permitir a possibilidade da proteção de IGs para serviços.

A LPI define, em seu artigo 177, o que deve ser entendido como uma indicação de procedência, ou seja, o nome geográfico de país, cidade, região ou localidade de seu território que se tenha tornado conhecido como centro de extração, produção ou fabricação de determinado produto ou de prestação de determinado serviço (BRASIL, 1996). A noção de ter-se tornado conhecido vem sendo compreendida como a reputação adquirida por determinado local, como centro de produção, extração ou comercialização de determinados produtos ou serviços.

Por denominação de origem, o artigo 178 da LPI estabelece ser o nome geográfico de país, cidade, região ou localidade de seu território, aquele que designe produto ou serviço cujas qualidades ou características se devam exclusiva ou essencialmente ao meio geográfico, incluídos fatores naturais e humanos (BRASIL, 1996). Diferentemente da indicação de procedência, vista no parágrafo anterior, na denominação de origem, o produto ou o serviço deverá ter características ou especificidades que dependam do meio geográfico no qual o mesmo é produzido ou prestado. Conforme Cerdan (2013):

[...] o conceito de indicação geográfica valoriza particularidades de diferentes produtos de diferentes regiões, cria um fator diferenciador para produto e território, que apresentam originalidade e características próprias. 
Afinal, as indicações geográficas não diferenciam somente os produtos ou serviços, mas também os territórios." (CERDAN, 2013, p. 127).

Dentro da seara jurídica, é comum pensar-se nas leis como uma resposta às demandas sociais. No caso da incorporação das IGs, no ordenamento jurídico brasileiro, resta claro ser a mesma uma resposta às pressões internacionais, muito mais do que às demandas internas da sociedade brasileira que, praticamente, desconhecia (como parece ainda desconhecer) esses institutos.

No plano da concessão de registro de indicações geográficas no Brasil de 2002 a 2013, observa-se na tabela 1 que a maior parte dos registros de IGs reconhecidas é de residentes no país, com $82,61 \%$ dos registros concedidos, enquanto os registros de IGs de não residentes representam apenas 17,39\% .

Observa-se que a maior parte dos registros concedidos é de indicação de procedência $(65,22 \%)$, sendo $34,78 \%$ os registros de denominação de origem. Essa diferença numérica entre os dois tipos de IG, possivelmente, resulta dos requisitos necessários à obtenção de cada uma das espécies de proteção. Cabe destacar que $100 \%$ dos registros de não residentes são da espécie denominação de origem. Em relação aos residentes, há uma participação de 78,94\% de Indicação de Procedência e $21,06 \%$ de denominação de origem.

Quadro 1. Número de registros de IGs concedidos no Brasil, por domicílio do proponente e por espécie de IG entre 1999 a 2013

\begin{tabular}{|c|c|c|c|c|c|}
\hline \multirow{2}{*}{ Ano } & \multirow{2}{*}{$\begin{array}{l}\text { Número de registro } \\
\text { concedido de } \\
\text { Indicações } \\
\text { Geográficas }\end{array}$} & \multicolumn{2}{|c|}{ Domicílio do residente } & \multicolumn{2}{|c|}{ Espécie de Indicação Geográfica } \\
\hline & & Residente & Não Residente & $\begin{array}{l}\text { Indicação de } \\
\text { Procedência }\end{array}$ & $\begin{array}{c}\text { Denominação de } \\
\text { Origem }\end{array}$ \\
\hline 1999 & 1 & - & 1 & - & 1 \\
\hline 2000 & 1 & - & 1 & & 1 \\
\hline 2001 & - & - & - & - & - \\
\hline 2002 & 1 & 1 & - & 1 & - \\
\hline 2003 & 1 & & 1 & & 1 \\
\hline 2004 & - & - & - & - & - \\
\hline 2005 & 1 & 1 & - & 1 & - \\
\hline 2006 & 1 & 1 & - & 1 & - \\
\hline 2007 & 1 & 1 & - & 1 & - \\
\hline 2008 & - & - & - & - & - \\
\hline 2009 & 3 & 2 & 1 & 2 & 1 \\
\hline 2010 & 2 & 2 & - & 1 & 1 \\
\hline 2011 & 6 & 6 & - & 5 & 1 \\
\hline 2012 & 21 & 18 & 3 & 13 & 8 \\
\hline 2013 & 7 & 6 & 1 & 5 & 2 \\
\hline Total & 46 & 38 & 8 & 30 & 16 \\
\hline \multicolumn{2}{|c|}{ Participação (\%) } & 82,61 & 17,39 & 65,22 & 34,78 \\
\hline
\end{tabular}

Fonte: INPI. 
Em relação aos registros de residentes, cabe destacar que o Estado do Rio Grande do Sul apresenta uma maior quantidade de registros concedidos, perfazendo 26,3\% do total. Em seguida, aparece o Estado de Minas Gerais, com 21,1\%, conforme a tabela 2. O Estado do Rio de Janeiro apresenta 37,5\% das denominações de origem concedidas a residentes, que são relacionadas aos diferentes tipos de pedras ornamentais ali existentes.

Ressalta-se o registro de uma indicação de procedência concedida referente ao Vale do Submédio São Francisco, em 2009, relacionada à produção de uva de mesa e manga. Nesse caso, a área delimitada abrange os estados de Pernambuco e Bahia. A concessão do registro da IG no Brasil não está atrelada ao limite geográfico da Unidade da Federação, para fins de delimitação.

Quadro 2. IGs concedidas no Brasil entre 2002 e 2013, por Unidade da Federação e por espécie de IG

\begin{tabular}{|c|c|c|c|c|c|c|c|c|c|c|c|c|c|c|c|c|c|}
\hline \multirow{2}{*}{ Ano } & \multirow{2}{*}{$\begin{array}{l}\text { Espécie de } \\
\text { IG }\end{array}$} & \multicolumn{15}{|c|}{ Unidade da Federação } & \multirow{2}{*}{ Tota } \\
\hline & & RS & MG & RJ & ES & SP & PB & $\mathrm{CE}$ & $\mathrm{PI}$ & TO & PR & $\mathrm{AL}$ & $\mathrm{PE}$ & SE & $\mathrm{RN}$ & $\mathrm{PE} / \mathrm{BA}$ & \\
\hline \multirow{2}{*}{2002} & IP & 1 & - & - & - & - & - & - & - & - & - & - & - & - & - & - & 1 \\
\hline & DO & - & - & - & - & - & - & - & - & - & - & - & - & - & - & - & - \\
\hline \multirow{2}{*}{2005} & IP & - & 1 & - & - & - & - & - & - & - & - & - & - & - & - & - & 1 \\
\hline & DO & - & - & - & - & - & - & - & - & - & - & - & - & - & - & - & - \\
\hline \multirow{2}{*}{2006} & IP & 1 & - & - & - & - & - & - & - & - & - & - & - & - & - & - & 1 \\
\hline & DO & - & - & - & - & - & - & - & - & - & - & - & - & - & - & - & - \\
\hline \multirow{2}{*}{2007} & IP & - & - & 1 & - & - & - & - & - & - & - & - & - & - & - & - & 1 \\
\hline & DO & - & - & - & - & - & - & - & - & - & - & - & - & - & - & - & - \\
\hline \multirow{2}{*}{2009} & IP & 1 & - & - & - & - & - & - & - & - & - & - & - & - & - & 1 & 2 \\
\hline & DO & - & - & - & - & - & - & - & - & - & - & - & - & - & - & - & - \\
\hline \multirow{2}{*}{2010} & IP & 1 & - & - & - & - & - & - & - & - & - & - & - & - & - & - & 1 \\
\hline & DO & 1 & - & - & - & - & - & - & - & - & - & - & - & - & - & - & 1 \\
\hline \multirow{2}{*}{2011} & IP & 1 & 2 & - & 1 & - & - & - & - & 1 & - & - & - & - & - & - & 5 \\
\hline & DO & - & - & - & - & - & - & 1 & - & - & - & - & - & - & - & - & 1 \\
\hline \multirow{2}{*}{2012} & IP & 2 & 3 & - & 2 & 1 & 1 & - & 1 & - & 1 & - & 1 & 1 & - & - & 13 \\
\hline & DO & 1 & - & 3 & - & - & - & - & - & - & - & 1 & - & - & - & - & 5 \\
\hline \multirow{2}{*}{2013} & IP & 1 & 1 & - & - & 1 & 1 & - & - & - & - & - & - & - & 1 & - & 5 \\
\hline & DO & - & 1 & - & - & - & - & - & - & - & - & - & - & - & - & - & 1 \\
\hline \multicolumn{2}{|c|}{ Total } & 10 & 8 & 4 & 3 & 2 & 2 & 1 & 1 & 1 & 1 & 1 & 1 & 1 & 1 & 1 & 38 \\
\hline
\end{tabular}

Fonte: INPI

A importância relativa da IG no Brasil leva à necessidade de organização das comunidades e dos produtores individuais, de modo a utilizar esse instrumento como forma de governança das relações entre os agentes envolvidos (VITROLLES, 2013). Segundo Cedran (2013), os custos de produção são significativos nos produtos 
agrícolas e nos agroindustriais, fato que produz a necessidade de uma coordenação dos agentes envolvidos:

as IGs são, com freqüência, originárias de regiões agrícolas desfavorecidas, onde os produtores não têm condições de reduzir o custo de produção." [...] "Um dos elementos-chaves das IGs foi de promover, criar e implementar novas formas de governança local e de regulação entre os diferentes agentes da cadeia produtiva. A emergência de comitês interprofissionais e a busca de uma melhor harmonização dos interesses entre os diferentes agentes permitiram o fortalecimento da região e dos produtores (CERDAN, 2013, p. 130).

No segmento agroalimentar, a indicação geográfica pode ser utilizada como instrumento de diminuição de incerteza e risco relacionado à qualidade de produção ao longo dessa cadeia. Conforme Chalita et.al(2009):

\begin{abstract}
a diversidade de produtos agroalimentares e os problemas contemporâneos de segurança alimentar conduzem à incerteza sobre a qualidade dos produtos seja para os diferentes elos da cadeia produtiva, seja para o consumidor final. As Denominações de Origem Protegidas (DOP) ou Indicações Geográficas Protegidas (IGP) ou as Certificações de Conformidade (CC) são instrumentos cada vez mais presentes neste mercado. As certificações surgiram, primeiramente, nos países europeus mediterrâneos, com objetivo de proteger os produtores familiares locais, a exemplo da Appélation d'Origine Controllée (AOC) para os vinhos franceses e, posteriormente, utilizados como instrumentos de política agrícola e política da qualidade. (CHALITA el.al, 2009, p. 68).
\end{abstract}

A IG é um instrumento que pode refletir as dinâmicas territoriais dos agentes envolvidos e contribuir para o aumento do valor adicionado dos produtos agroalimentares decorrente da estruturação de um modelo de negócio (VITROLLES, 2013).

Dessa forma, o processo de obtenção do registro de indicação geográfica demanda uma governança dos agentes envolvidos, tais como, produtores, processadores, autoridades públicas e institutos de pesquisas para dirimir os potenciais conflitos e garantir a reputação e qualidade dos bens produzidos na delimitação geográfica (BELLETTI et. al, $2015 \mathrm{a}, \mathrm{b}$ ).

Os produtores utilizam $\mathrm{o}$ instrumento de indicação geográfica como mecanismo de diferenciação aos concorrentes, busca de preço prêmio pelos produtos disponibilizados ao mercado e a constituição de novos canais de distribuição e de marketing (QUIÑONES-RUIZ et al, 2016).

O registro de IG pode impulsionar outras atividades econômicas na região como turismo, proporcionando geração de emprego e renda locais (BELLETTI et al, $2015 a, b)$.

Ao mesmo tempo, torna-se importante destacar a pouca familiaridade com a figura da IG, tanto por parte dos produtores locais quanto pelo público, no Brasil, 
como dito antes. Encontram-se referências em estudos de caso realizados sobre a IP de Pelotas, comparando-a a uma espécie de marca de certificação ${ }^{3}$.

Um sinal requerido como marca de certificação junto ao INPI também receberá a proteção, desde que observados os requisitos legais para a concessão e a manutenção da tutela pelo direito industrial. Entretanto, o escopo de tal proteção é muito distinto daquele obtido por meio do reconhecimento da IG.

A certificação atesta que o produto ou serviço foi submetido a uma avaliação de conformidade, geralmente de terceira parte, garantindo a isenção do agente certificador em relação aos agentes produtores. Trata-se, pois, de "[...] um processo sistematizado, com regras definidas, devidamente acompanhado e avaliado de forma a propiciar adequado grau de confiança de que determinado produto, processo ou serviço atenda a requisitos preestabelecidos em normas e regulamentos" (GONÇALVES, 2007, p. 287).

A IG pode ser utilizada como uma forma de controle da produção, tendo em vista a existência do regulamento de uso apresentado com o pedido de reconhecimento perante o INPI, e a existência de um conselho regulador que verifica o cumprimento do referido regulamento. Contudo, esse processo diverge do processo de certificação que, nos moldes do mercado atual, é realizado por um terceiro que não mantém qualquer tipo de relação com os produtores ou prestadores de serviço. Ou seja, a "[...] avaliação de conformidade é feita por organismos independentes da relação comercial, com o objetivo de atestar publicamente e por escrito que o produto, processo ou serviço está em conformidade com os requisitos especificados." (GONÇALVES, 2007, p. 287).

A falta de familiaridade com o conceito de IG e suas espécies - indicação de procedência e denominação de origem - ainda é comum no Brasil, onde produtos detentores de certa tradição existem, mas essa não era (é) vista como um diferencial de mercado, com o mesmo vigor que se observa esse fenômeno na Europa. Por isso, percebe-se ainda a pouca familiaridade com essas figuras e a necessidade da presença de instituições públicas e/ou privadas na estruturação dos agentes locais para a formalização do pedido de reconhecimento da IG.

O requerimento do reconhecimento desses tipos de sinais distintivos demanda uma estrutura nem sempre existente nos locais destacados por sua tradição/reputação ou por especificidades ligadas ao terroir que criam diferenciação aos produtos locais no Brasil. Tal fato pode comprometer, no médio e longo prazos, a governança das estruturas organizacionais criadas para dar suporte à solicitação de um registro de IG.

Diante desse cenário, muitos produtores brasileiros de segmentos tradicionais começaram a perceber as IGs como uma ferramenta de diminuição da assimetria da informação e de segmentação de mercado, nos quais a concorrência deixa de ser por

\footnotetext{
${ }^{3}$ A marca de certificação é um dos tipos de marcas regulados pela LPI no capítulo de marcas dessa Lei. Assim, no artigo 123 II, tem-se: "marca de certificação: aquela usada para atestar a conformidade de um produto ou serviço com determinadas normas ou especificações técnicas, notadamente quanto à qualidade, natureza, material utilizado e metodologia empregada;" (BRASIL, 1996). Como disposto no artigo de Lei, a marca de certificação é figura muito distinta da indicação geográfica.
} 
preço, passando a ser por diferenciação, como será discutido, no próximo tópico, sobre os produtores de doces de Pelotas.

\section{Doces de Pelotas - tradição e história}

Este tópico do artigo teve como principal referência à documentação de pedido de reconhecimento da IP de Pelotas. Destaca-se a relevância de tal documentação para a comprovação da reputação. Com este fito, expressiva quantidade de artigos ordinários da imprensa, publicados ao longo de décadas, aportou um conjunto de informações relevantes para a divulgação da tradição em torno da produção dos doces de Pelotas. As informações fornecidas no processo administrativo de reconhecimento da IP foram essenciais à composição deste tópico.

A região de Pelotas localiza-se na metade sul do Estado do Rio Grande do Sul. Em termos de contribuição do Produto Interno Bruto - PIB, o município de Pelotas está em nono lugar na classificação na participação do PIB do Estado do Rio Grande do Sul no ano de 2010, com uma participação em torno de $2 \%$ do PIB gaúcho. De acordo com a tabela 3, trata-se de um dos principais municípios da metade sul do Rio Grande do Sul. Em termos de composição do PIB do Município de Pelotas, a parte agropecuária tem uma participação relativamente pouco significativa, isso porque o PIB está concentrado nas atividades industriais de baixo valor adicionado e de serviços.

A região de Pelotas tem sido uma das áreas do Estado do Rio Grande do Sul com baixo crescimento econômico e sente os efeitos de falta de atividades econômicas que sejam catalizadoras para outras atividades.

A economia da região de Pelotas está resumida a atividades de serviços de baixo valor adicionado relativo, em que pese a existência no município de uma universidade federal, qual seja, a Universidade Federal de Pelotas - UFPEL, e outras infraestruturas com potencial de dinamizar a economia pelotense (LENGLER et al, 2008). 
Quadro 3. Produto Interno Bruto (PIB), Valor Adicionado Bruto (VAB), PIB per capita e população dos 10 maiores municípios segundo o PIB total do Estado do Rio Grande do Sul - 2011

\begin{tabular}{|c|c|c|c|c|c|c|c|c|c|c|c|c|c|c|}
\hline \multirow{3}{*}{ unicípios } & \multicolumn{5}{|c|}{ Produto Interno Bruto } & \multicolumn{6}{|c|}{ Valor Adicionado Bruto } & \multirow{3}{*}{$\begin{array}{c}\begin{array}{c}\text { Produto } \\
\text { Interno } \\
\text { Bruto per } \\
\text { capita }\end{array} \\
\text { (R\$) }\end{array}$} & \multicolumn{2}{|c|}{ População } \\
\hline & \multirow{2}{*}{$\begin{array}{c}\text { Valor } \\
\text { (R\$1 000) }\end{array}$} & \multirow{2}{*}{$\begin{array}{c}\text { Variação } \\
\text { nominal } \\
(\%)\end{array}$} & \multicolumn{2}{|c|}{ Participação (\%) } & \multirow{2}{*}{$\begin{array}{c}\text { Posição } \\
\text { no } \\
\text { Ranking } \\
\text { em } 2010\end{array}$} & \multicolumn{3}{|c|}{ Variação nominal (\%) } & \multicolumn{3}{|c|}{ Estrutura (\%) } & & \multirow{2}{*}{ Habitante } & \multirow{2}{*}{$\begin{array}{c}\text { Participakãã } \\
(\%)\end{array}$} \\
\hline & & & 2011 & 2010 & & Agropecuária & Indústria & Serviços & Agropecuária & Indústria & Serviços & & & \\
\hline Porto Alegre & 45.506 .017 & 6,0 & 17,26 & 17,01 & $1^{\circ}$ & 0,8 & 0,9 & 6,1 & 0,06 & 14,64 & 85,30 & 32.203 & 1.413 .094 & 13,17 \\
\hline $\begin{array}{l}\text { Caxias do } \\
\text { Sul }\end{array}$ & 16.636 .859 & 8,1 & 6,31 & 6,10 & $3^{\circ}$ & 22,2 & 6,3 & 6,6 & 1,43 & 44,83 & 53,75 & 37.697 & 441.332 & 4,11 \\
\hline Canoas & 15.515 .129 & $-13,9$ & 5,89 & 7,14 & $2^{\circ}$ & $-18,3$ & $-42,7$ & 5,7 & 0,03 & 27,63 & 72,34 & 47.711 & 325.189 & 3,03 \\
\hline Rio Grande & 8.194 .552 & 5,3 & 3,11 & 3,08 & $4^{\circ}$ & $-19,7$ & 1,4 & 6,7 & 2,30 & 34,43 & 63,28 & 41.376 & 198.049 & 1,85 \\
\hline Gravataí & 7.304 .668 & 5,8 & 2,77 & 2,74 & $5^{\circ}$ & $-2,1$ & 1,0 & 9,6 & 0,26 & 53,80 & 45,94 & 28.376 & 257.428 & 2,40 \\
\hline Triunfo & 5.932 .342 & $-9,1$ & 2,25 & 2,58 & $6^{\circ}$ & $-6,4$ & $-13,0$ & $-2,9$ & 1,00 & 76,30 & 22,71 & 227.537 & 26.072 & 0,24 \\
\hline $\begin{array}{l}\text { Novo } \\
\text { Hamburgo }\end{array}$ & 5.502 .785 & 2,8 & 2,09 & 2,12 & $7^{\circ}$ & 0,6 & $-6,0$ & 3,4 & 0,38 & 26,45 & 73,17 & 23.010 & 239.151 & 2,23 \\
\hline Pelotas & 5.422 .372 & 19,2 & 2,06 & 1,80 & $9^{\circ}$ & $-1,6$ & 37,4 & 14,7 & 2,65 & 21,74 & 75,61 & 16.488 & 328.865 & 3,06 \\
\hline Passo Fundo & 4.989 .677 & 9,8 & 1,89 & 1,80 & $10^{\circ}$ & 32,9 & 11,1 & 8,2 & 2,19 & 16,80 & 81,01 & 26.814 & 186.083 & 1,73 \\
\hline $\begin{array}{l}\text { Santa Cruz } \\
\text { do Sul }\end{array}$ & 4.943 .635 & 4,7 & 1,88 & 1,87 & $8^{\circ}$ & 13,3 & $-7,4$ & 15,0 & 3,25 & 40,61 & 56,14 & 41.474 & 119.199 & 1,11 \\
\hline Total & 119.948 .035 & - & 45,50 & 46,24 & - & - & - & - & - & - & - & - & 3.534 .462 & 32,93 \\
\hline $\begin{array}{l}\text { Rio Grande } \\
\text { do Sul }\end{array}$ & 263.633 .398 & 4,4 & 100,00 & 100,00 & - & 9,9 & $-4,4$ & 7,1 & 9,18 & 26,86 & 63,96 & 24.563 & 10.733 .030 & 100,00 \\
\hline
\end{tabular}

Fonte: FEE/Centro de Informações Estatísticas/Núcleo de Contabilidade Social.

IBGE/Diretoria de Pesquisas/Coordenação de Contas Nacionais. 
O processo histórico de ocupação do território compreendido como Pelotas deu-se ainda no século XVIII onde, inicialmente, instalou-se uma rede de criação e comércio de gado. Posteriormente, em função de alguns ciclos migratórios, a região também começou a ser utilizada para a produção de charque.

Essa produção era exportada para a região nordeste, onde havia demanda causada pela atividade de exploração da cana-de-açúcar. Foi a partir da interação entre os produtores de açúcar e os de charque que se criou a competência da produção de doces pelas senhoras pelotenses para servir em ocasiões especiais. Com a diminuição do consumo do charque, houve a necessidade de reconfiguração da atividade econômica. Nesse sentido, as mulheres da aristocracia pelotense buscaram o trabalho manual como alternativa de geração de atividade econômica, resultando na produção comercial de doces (FERREIRA et al, 2008).

As doceiras puderam contar tanto com os frutos trazidos e introduzidos pelos portugueses na biodiversidade brasileira, como também com os frutos já consumidos pelos índios no Brasil, como eram os casos do cacau, goiaba e abacaxi, para reproduzir ou adaptar receitas tradicionais portuguesas. As adaptações realizadas deram um tom de apropriação muito pertinente às tradições portuguesas, culminando por aculturar, cada vez mais, os doces ao paladar brasileiro.

Em 1832, ocorre a emancipação do Município de Pelotas, o que estimula um número cada vez maior de fazendeiros e charqueadores a construir residências, adotando a localidade como local de moradia. Após a emancipação, surge a primeira fábrica de bolachas doces. Além disso, nos encontros sociais, os pelotenses foram mantendo o costume de comer os doces já mencionados, motivando, assim, a manutenção da tradição.

O doce de Pelotas, na primeira metade do século XIX, fazia-se presente nas festividades católicas, em seus rituais, logo, tornando-se objeto de demanda por parte de autoridades políticas, dada a fama angariada. Entretanto, apenas no final do século XIX, com a decadência das charquearias, os doces passaram a ocupar um lugar mais formal na renda das famílias. Por ser um trabalho eminentemente feminino, evitavase dar a conhecer quem seria a doceira, pois o trabalho feminino era visto como empobrecimento e degradação familiar. Só em 1959, essa situação mudou, tendo em vista uma publicação da Editora Globo sobre os doces de Pelotas. Tal publicação tirou do anonimato suas produtoras, consagrando-as com um status social diferenciado.

Além dessas doceiras, há outras fontes para a sedimentação da tradição dos doces de Pelotas, como o fim da escravidão, que possibilitou aos negros recémlibertos venderem os doces em seus tabuleiros ou o surgimento, ainda no final do século XIX, das primeiras confeitarias da região, bem como a imigração de franceses e alemães que também investiram nesse tipo de negócio.

Em 1986, os produtores de doces, o poder público local e os comerciantes organizaram a Feira Nacional de Doce - FENADOCE, um evento inicialmente bianual. A partir de 1995, tal evento tornou-se anual e, sob a responsabilidade da Câmara de Dirigentes Lojistas de Pelotas, houve um impulso maior ao evento.

A FENADOCE tem sido um evento complementar para a disseminação da produção de doces derivados de frutas e doces tradicionais de confeitaria. Além disso, 
a Feira constitui um locus de presença dos agentes das diferentes etapas da cadeia produtiva. Contudo, esse evento tem tido uma redução do impacto relativo sobre os agentes da cadeia produtiva de doces, principalmente na venda desses produtos, já que os compradores vão direto às lojas comerciais (MARCHI et al, 2009).

Em 2003, a Assembleia Legislativa do Rio Grande do Sul aprovou a Lei ${ }^{\circ}$ 11.919 de 06/06/2003, declarando como patrimônio cultural do estado os doces de Pelotas. Hoje, muitas famílias vivem da produção e comercialização desses doces.

A aglomeração de produtores de doces na região de Pelotas apresenta uma interação entre os agentes da cadeia de produção, construída ao longo do tempo. As empresas produtoras de doces apresentam economias de escala restrita, por conta de seus portes e pelas características do mercado, pela falta de canais de distribuição adequados e pelo fato de o produto ser perecível (MARCHI et al, 2009).

No próximo tópico, destacar-se-á a estruturação da indicação de procedência dos doces tradicionais de confeitaria e de frutas de Pelotas.

\section{5 indicação de procedência dos doces de Pelotas}

A IP para doces tradicionais de confeitaria e de frutas de Pelotas está baseada nos quesitos: tradição, localidade e qualidade, conforme dados constantes no processo de requerimento do registro da IP junto ao INPI. Importante destacar as argumentações de Casabianca et.al, (2013) quando apontam que as relações sociais se exprimem em torno de um produto contribuindo para the dar sentido (CASABIANCA et.al., 2013, p. 216).

Seguindo suas reflexões sobre a questão da tradição e do saber, os autores ainda acrescentam que "[...] um saber não é estático [...]. Longe de ser um 'produtomoda', o produto típico não é, contudo, fixo e as transmissões intergeracionais repousam sobre a capacidade de uma dada geração de mantê-lo vivo." (CASABIANCA et.al., 2013, p. 218). Pode-se destacar que, quando a documentação da IP de Pelotas remete à tradição, torna esta um dos elementos centrais para 0 reconhecimento do sinal como tal.

Nesta mesma documentação, sobre a qual se deterá esta parte do artigo, encontram-se também dados referentes às localidades compreendidas como pertencentes à delimitação geográfica realizada para a obtenção do reconhecimento da IP de Pelotas. As localidades presentes na documentação são: os municípios de Capão do Leão, São Lourenço do Sul, Morro Redondo, Turuçu e Arroio do Padre, todos no Rio Grande do Sul, Brasil.

Destaca-se que esses municípios apresentam uma base econômica em produtos e serviços de baixo valor adicionado, por isso ter um preço prêmio em seus produtos e serviços poderá aumentar a renda local.

No regulamento técnico, constante do processo de requerimento do registro da IP, são apresentados a descrição, os requisitos de qualidade e as características específicas dos doces tradicionais da área geográfica acima indicada. Os doces tradicionais de Pelotas, produzidos nas regiões descritas de forma artesanal, admitem algumas variações, como peso ou formato, desde que estas não conflitem com o 
disposto no regulamento de uso. É importante pensar-se em variações, pois já há certo consenso sobre a ideia que tradicional não significa estático. A tradição possui sua própria dinâmica e esta é essencial para a sua manutenção.

As características dos doces - como composição obrigatória, opcional e alternativa de ingredientes, qualidade destes, processo básico de produção, modelagem, acabamento, conservação, armazenagem, transporte, exposição e rotulagem - aparecem descritas no regulamento de uso.

Há um conselho regulador que define os padrões dos doces produzidos, observados por um sistema de rastreamento de lotes, previsto no regulamento de uso, no qual encontra-se disposto o controle a ser realizado na própria produção, por cada doceiro. Ou seja, o sistema caracteriza-se pelo autocontrole, conforme consta da documentação apresentada ao INPI, e visa a garantir a tipicidade e a qualidade dos doces, assim como a rastreabilidade dos lotes no mercado. Além disso, a documentação prevê controle referente à segurança dos processos de fabricação.

As empresas autorizadas a utilizar a IP deverão atender aos critérios de tipicidade, qualidade e localidade. Dessa forma, são estipulados na documentação de requerimento da IP de Pelotas que os doces sejam:

- produzidos por sociedades empresárias formalizadas conforme a legislação brasileira, associadas e em situação regular junto à Associação dos Produtores de Doce Pelotas, localizadas e produzindo na área geográfica Pelotas;

- produzidos de acordo com as receitas e características dos doces tradicionais, descritas no regulamento e que mantenham características tradicionais;

- rastreados no mercado por meio do sistema proposto pelo Regulamento Técnico da Associação Doce Pelotas;

- produzidos em infraestrutura adequada para manutenção da segurança alimentar e em condições adequadas conforme a legislação brasileira vigente;

- produzidos por equipes treinadas nos conceitos relativos à IP e em segurança alimentar.

O regulamento apresentado dispõe os padrões de qualidade dos doces, dos ingredientes e da infraestrutura para a produção. Outra informação presente na documentação em apreço relaciona-se à qualificação da empresa que, situada na área geográfica demarcada, deseje utilizar o sinal geográfico reconhecido como direito de propriedade industrial. Para fazer uso desse sinal, a empresa candidata, obrigatoriamente, passará por procedimentos bem definidos, devendo, inclusive, comprová-los com a apresentação de registros formais. Um desses procedimentos visa ao treinamento padrão sobre os conceitos vinculados à indicação de procedência. Esse treinamento deverá ser ministrado pelos membros do conselho regulador ou da Associação de Produtores de Doce de Pelotas. Para esse procedimento, a candidata deverá destinar, no mínimo, 75\% dos membros da equipe de produção e 100\% de seus diretores para o treinamento e todos terão que ter $90 \%$ de frequência.

Tal ação demonstra a importância dada à difusão dos conceitos da IP Pelotas, expondo uma estratégia de apropriação e empoderamento daqueles que são os titulares do sinal. 
Além disso, há treinamento, destinado à equipe de produção e aos diretores das sociedades empresárias interessadas no uso da IP, sobre boas práticas de fabricação de alimentos, visando a atender o estipulado pela legislação de vigilância sanitária nacional. Isso revela outra preocupação dos titulares e gestores da IP: a questão da qualidade que, como visto anteriormente, destaca-se por ser um dos elementos essenciais nos discursos sobre IGs e suas espécies, quais sejam, a IP e a denominação de origem.

A delimitação geográfica, constante do requerimento de concessão da IP, foi possibilitada por meio de um laudo técnico, emitido pela Secretaria do Desenvolvimento e dos Assuntos Internacionais do Estado do Rio Grande do Sul SEDAI, a partir de estudos técnicos realizados pelo Serviço Brasileiro de Apoio as Micro e Pequenas Empresas - SEBRAE/RS e pela UFPEL a partir de um termo de cooperação técnica. De acordo com Casabianca et al., "[...] a delimitação é vista como um processo de negociação e de formação de compromissos, onde os argumentos de ordem técnica são dominantes, mas não exclusivos." (CASABIANCA et.al., 2013, p. 208-209). 
Quadro 4. Portfolio de produtos abarcados pela indicação de procedência e seus requisitos de produção pelos associados

\begin{tabular}{|c|c|c|}
\hline Produtos & Características & Restrições de Produção \\
\hline Amanteigado & $\begin{array}{l}\text { Descrição: doce bastante delicado preparado com amêndoas, gemas e açúcar. } \\
\text { Formato: Formato arredondado ou em pequenas esferas unidas e cobertas } \\
\text { totalmente por fondant. } \\
\text { Sabor e textura: doce de textura macia e sabor predominante de amêndoas e } \\
\text { gemas. } \\
\text { Conservação: a temperatura ambiente (que não seja superior a } 25^{\circ} \mathrm{C} \text { ) por no } \\
\text { máximo } 7 \text { dias. O prazo de validade deste doce é considerado enquanto se } \\
\text { mantiverem as características originais de sabor, apresentação, textura, cor e } \\
\text { principalmente ausência de desenvolvimento de contaminação microbiológica. } \\
\text { Aspectos nutricionais: este doce não pode conter glúten na sua composição, } \\
\text { porém pode conter traços deste, devido à forma artesanal de preparo e } \\
\text { possibilidade de contato com ingredientes que contenham glúten. }\end{array}$ & $\begin{array}{l}\text { Proibições de } \\
\text { alterações da receita: } \\
\text { Uso de batata cozida e } \\
\text { amassada. Não são } \\
\text { permitidos os } \\
\text { melhoradores de } \\
\text { produtos, tais como } \\
\text { anti-mofo, } \\
\text { conservantes, aditivos, } \\
\text { corantes, } \\
\text { emulsificantes. }\end{array}$ \\
\hline $\begin{array}{l}\text { Beijinho de } \\
\text { Coco }\end{array}$ & $\begin{array}{l}\text { Descrição: doce de gemas, coco e açúcar, em formato esférico coberto com } \\
\text { fondant e decorado com confeitos prateados. Formato: seu formato é } \\
\text { arredondado. } \\
\text { Sabor e textura: tem textura macia. O sabor é predominantemente de coco. } \\
\text { Conservação: temperatura ambiente (que não seja superior a } 25^{\circ} \mathrm{C} \text { ) por } 7 \text { dias. O } \\
\text { prazo de validade deste doce é considerado enquanto se mantiverem as } \\
\text { características originais de sabor, apresentação, textura, cor e principalmente } \\
\text { ausência de desenvolvimento de contaminação microbiológica. } \\
\text { Aspectos nutricionais: este doce não pode conter glúten na sua composição, } \\
\text { porém pode conter traços deste, devido à forma artesanal de preparo e } \\
\text { possibilidade de contato com ingredientes que contenham glúten. }\end{array}$ & $\begin{array}{l}\text { Proibições de } \\
\text { alterações da receita: } \\
\text { Não são permitidos os } \\
\text { melhoradores de } \\
\text { produtos, tais como } \\
\text { anti-mofo, } \\
\text { conservantes, aditivos, } \\
\text { corantes, } \\
\text { emulsificantes. }\end{array}$ \\
\hline $\begin{array}{l}\text { Broinha de } \\
\text { Coco }\end{array}$ & $\begin{array}{l}\text { Descrição: Doce de coco, gemas e açúcar em formato esférico e com aspecto } \\
\text { brilhoso em função da glicose em sua cobertura. Formato: seu formato é } \\
\text { arredondado. } \\
\text { Sabor e textura: tem textura macia. O sabor é predominantemente de coco. } \\
\text { Conservação: temperatura ambiente (que não seja superior a } 25^{\circ} \mathrm{C} \text { ) por } 7 \text { dias. O } \\
\text { prazo de validade deste doce é considerado enquanto se mantiverem as } \\
\text { características originais de sabor, apresentação, textura, cor e principalmente } \\
\text { ausência de desenvolvimento de contaminação microbiológica. } \\
\text { Aspectos nutricionais: este doce não pode conter glúten na sua composição, } \\
\text { porém pode conter traços deste, devido à forma artesanal de preparo e } \\
\text { possibilidade de contato com ingredientes que contenham glúten. }\end{array}$ & $\begin{array}{l}\text { Proibições de } \\
\text { alterações da receita: } \\
\text { Não são permitidos os } \\
\text { melhoradores de } \\
\text { produtos, tais como } \\
\text { anti-mofo, } \\
\text { conservantes, aditivos, } \\
\text { corantes, } \\
\text { emulsificantes. }\end{array}$ \\
\hline Camafeu & $\begin{array}{l}\text { Descrição: O camafeu é um doce cuja massa é feita de nozes chilena ou pecan. É } \\
\text { glaceado e é decorado com uma } 1 / 4 \text { de noz chilena. Tem formato arredondado, } \\
\text { levemente afinado nas extremidades. É uma réplica de um adereço usado desde } \\
\text { antigamente para roupas chamado "camafeu". Formato: o camafeu tem formato } \\
\text { arredondado, podendo ser levemente afinado nas pontas. Sabor e textura: é um } \\
\text { doce de textura macia com sabor predominantemente de nozes. Conservação: } \\
\text { não requer refrigeração e mantém-se por } 10 \text { dias a temperatura ambiente (que } \\
\text { não seja superior a } 25^{\circ} \mathrm{C} \text { ). O prazo de validade deste doce é considerado } \\
\text { enquanto se mantiverem as características originais de sabor, apresentação, } \\
\text { textura, cor e principalmente ausência de desenvolvimento de contaminação } \\
\text { microbiológica. Aspectos nutricionais: este doce não pode conter glúten na sua } \\
\text { composição, porém pode conter traços deste, devido à forma artesanal de } \\
\text { preparo e possibilidade de contato com ingredientes que contenham glúten. Pode } \\
\text { conter traços de clara de ovo e não possui lactose. }\end{array}$ & $\begin{array}{l}\text { Proibiçõesde alterações } \\
\text { da receita: não é } \\
\text { permitido o uso de pão } \\
\text { de torrado; bolachas } \\
\text { moídas, farinha de } \\
\text { rosca, leite } \\
\text { condensado, } \\
\text { amendoim ou } \\
\text { similares. Não são } \\
\text { permitidos os } \\
\text { melhoradores de } \\
\text { produtos, tais como } \\
\text { anti-mofo, } \\
\text { conservantes, aditivos, } \\
\text { corantes, } \\
\text { emulsificantes. }\end{array}$ \\
\hline
\end{tabular}


Patricia P. Peralta, Mônica Christina R. Morgado, Elizabeth F. Silva, Dirceu Y. Teruya

Continuação

\begin{tabular}{|c|c|c|}
\hline Produtos & Características & Restrições de Produção \\
\hline $\begin{array}{l}\text { Doces } \\
\text { Cristalizados de } \\
\text { Frutas }\end{array}$ & $\begin{array}{l}\text { Descrição: São doces produzidos artesanalmente a partir de frutas e outros } \\
\text { hortifrutigranjeiros, com açúcar por meio da ação do calor (fervura, secagem). } \\
\text { Encontram-se nesta classificação: abóbora cristalizada, banana cristalizada, goiaba } \\
\text { cristalizada, pessegada cristalizada, laranja cristalizada, figo cristalizado, } \\
\text { marmelada, origone (pêssego seco), passa de pêssego. Têm uma textura macia, } \\
\text { tenra como a de frutas cristalizadas e com leve crocância na parte externa. Padrão } \\
\text { de qualidade: O padrão de qualidade segue o proposto pela legislação brasileira } \\
\text { para a identidade e qualidade desta classe de produtos. Não são permitidos os } \\
\text { melhoradores de produtos que não estejam permitidos pela legislação para este } \\
\text { tipo de produto, tais como anti-mofo, conservantes, aditivos, corantes, } \\
\text { emulsificantes. } \\
\text { Conservação: O prazo de validade deste doce é considerado enquanto se } \\
\text { mantiverem as características originais de sabor, apresentação, textura, cor e } \\
\text { principalmente ausência de desenvolvimento de contaminação microbiológica. } \\
\text { Mantém-se a temperatura ambiente (não superior a } 25^{\circ} \text { C), em ambiente seco, } \\
\text { afastado do sol e protegidos contra pragas e/ou outros contaminantes. A } \\
\text { conservação varia dependendo do ambiente e tipo de embalagem na qual é } \\
\text { armazenado. Composição das frutas cristalizadas: As frutas cristalizadas têm uma } \\
\text { característica básica de terem parte de sua água de constituição por açúcares, por } \\
\text { meio de tecnologia adequada, até o ponto de impedir sua deterioração. São } \\
\text { cortadas em pequenos cubos, de formato levemente irregular e quando prontos } \\
\text { são revestidos com açúcar cristal. No caso das laranjas cristalizadas, o formato do } \\
\text { corte é de pequenas tiras longitudinais na fruta. Tem uma umidade máxima de } \\
25 \% \text {, o suficiente para sua conservação no mercado. } \\
\text { Figo cristalizado, Abóbora cristalizada, Goiaba cristalizada, Pessegada cristalizada, } \\
\text { Laranja cristalizada, Marmelada. }\end{array}$ & $\begin{array}{l}\text { Aspectos nutricionais: } \\
\text { estes doces não podem } \\
\text { conter glúten nem } \\
\text { lactose, pois na sua } \\
\text { composição não são } \\
\text { adicionadas farinhas } \\
\text { nem laticínios. }\end{array}$ \\
\hline Fatias de Braga & $\begin{array}{l}\text { Descrição: uma massa composta principalmente de amêndoas, cortada em fatias } \\
\text { (quadradas) e cobertos com açúcar cristal. Pode ser decorado com flor de glacê } \\
\text { real cor de rosa e verde. Sabor bastante suave e textura macia. } \\
\text { Formato: Formato quadrado. Sabor e textura: é um doce de textura macia e } \\
\text { levemente úmido com sabor predominantemente de amêndoas. Conservação: } \\
\text { não requer refrigeração, e mantém-se por } 7 \text { dias a temperatura ambiente (que } \\
\text { não seja superior a } 25 \text { OC). O prazo de validade deste doce é considerado } \\
\text { enquanto se mantiverem as características originais de sabor, apresentação, } \\
\text { textura, cor e principalmente ausência de desenvolvimento de contaminação } \\
\text { microbiológica. Aspectos nutricionais: este doce não pode conter glúten na sua } \\
\text { composição, porém pode conter traços deste, devido à forma artesanal de } \\
\text { preparo e possibilidade de contato com ingredientes que contenham glúten. }\end{array}$ & $\begin{array}{l}\text { Proibições de } \\
\text { alterações da receita: } \\
\text { Não são permitidos os } \\
\text { melhoradores de } \\
\text { produtos, tais como } \\
\text { anti-mofo, } \\
\text { conservantes, aditivos, } \\
\text { corantes, } \\
\text { emulsificantes. }\end{array}$ \\
\hline Ninho & $\begin{array}{l}\text { Descrição: é um doce em forma de ninho de pássaros, cuja estrutura externa é } \\
\text { feita manualmente de fios de ovos enrolados, é recheado com ovos moles e } \\
\text { decorado com confeitos de açúcar prateados. Tem formato aproximado de } \\
\text { cilindro, com mais altura do que diâmetro. O recheio é colocado com uma } \\
\text { "pitanga", utensílio usado pelos doceiros em Pelotas. O ninho pode ser finalizado } \\
\text { no forno para dar uma leve dourada na sua superfície. } \\
\text { Formato: os ninhos têm formato aproximado de cilindro. Detalhe sobre a pitanga: } \\
\text { somente serão aceitos ninhos com a pitanga ultrapassando o limite superior do } \\
\text { cilindro de fios de ovos. Sabor e textura: é um doce de textura macia, percebe-se } \\
\text { sabor dos fios de ovos e ovos moles. Conservação: este doce se conserva em } \\
\text { refrigeração de } 0 \text { a } 40 C \text { por no máximo } 10 \text { dias. Para fins de transporte admite-se } \\
\text { que o ninho pode ser mantido por no máximo } 48 \text { horas a temperatura ambiente } \\
\text { (no máximo } 250 C \text { ). O prazo de validade deste doce é considerado enquanto se } \\
\text { mantiverem as características originais de sabor, apresentação, textura, cor e } \\
\text { principalmente ausência de desenvolvimento de contaminação microbiológica. } \\
\text { Aspectos nutricionais: este doce não pode conter glúten na sua composição, } \\
\text { porém pode conter traços deste, devido à forma artesanal de preparo e } \\
\text { possibilidade de contato com ingredientes que contenham glúten. Pode conter } \\
\text { traços de clara de ovo e não possui lactose. }\end{array}$ & $\begin{array}{l}\text { Proibição de alterações } \\
\text { da receita: não são } \\
\text { aceitos como ninhos } \\
\text { doces com recheios } \\
\text { diferentes de ovos } \\
\text { moles, como por } \\
\text { exemplo: doce de leite, } \\
\text { doce de confeiteiro. } \\
\text { Não são permitidos os } \\
\text { melhoradores de } \\
\text { produtos, tais como } \\
\text { anti-mofo, } \\
\text { conservantes, aditivos, } \\
\text { corantes, } \\
\text { emulsificantes. }\end{array}$ \\
\hline
\end{tabular}


A Indicação de Procedência como instrumento de diferenciação: o caso do Doce de Pelotas

Continuação

\begin{tabular}{|c|c|c|}
\hline Produtos & Características & Restrições de Produção \\
\hline Olho de Sogra & $\begin{array}{l}\text { Descrição: doce preparado com coco, gemas e açúcar, finalizado com ameixa } \\
\text { preta nos dois lados, no formato amendoado de um olho. Possui brilho específico } \\
\text { de doces cobertos com glicose. Formato: formato amendoado. Sabor e textura: é } \\
\text { um doce de textura macia e sua massa é homogênea com sabor } \\
\text { predominantemente de coco e ameixa. Conservação: temperatura ambiente por } \\
7 \text { dias (que não seja superior a } 25 \text { OC). O prazo de validade deste doce é } \\
\text { considerado enquanto se mantiverem as características originais de sabor, } \\
\text { apresentação, textura, cor e principalmente ausência de desenvolvimento de } \\
\text { contaminação microbiológica. Aspectos nutricionais: este doce não pode conter } \\
\text { glúten na sua composição, porém pode conter traços deste, devido à forma } \\
\text { artesanal de preparo e possibilidade de contato com ingredientes que contenham } \\
\text { glúten. Não possui lactose. }\end{array}$ & $\begin{array}{l}\text { Proibições de } \\
\text { alterações da receita: } \\
\text { não pode levar } \\
\text { farinhas, nem leite } \\
\text { condensado ou leite } \\
\text { em pó em sua } \\
\text { composição. Não são } \\
\text { permitidos os } \\
\text { melhoradores de } \\
\text { produtos, tais como } \\
\text { anti-mofo, } \\
\text { conservantes, aditivos, } \\
\text { corantes, } \\
\text { emulsificantes. } \\
\end{array}$ \\
\hline Papo de Anjo & $\begin{array}{l}\text { Descrição: é um doce de ovos, com formato de disco, sabor acentuado e envolto } \\
\text { em uma calda de açúcar, decorado com um cravo. Possui coloração amarelo claro } \\
\text { dourado. Formato: Formato arredondado. Sabor e textura: é um doce de textura } \\
\text { macia e úmida com sabor predominantemente de ovos. Conservação: } \\
\text { temperatura ambiente por } 7 \text { dias (que não seja superior a } 25 \text { OC) ou refrigerado } \\
\text { por } 10 \text { dias. Pode ser mantido em vidro, imersos em calda de açúcar. O prazo de } \\
\text { validade deste doce é considerado enquanto se mantiverem as características } \\
\text { originais de sabor, apresentação, textura, cor e principalmente ausência de } \\
\text { desenvolvimento de contaminação microbiológica. Aspectos nutricionais: Possui } \\
\text { glúten. Não possui lactose. }\end{array}$ & $\begin{array}{l}\text { Proibições de } \\
\text { alterações da receita: } \\
\text { Não são permitidos os } \\
\text { melhoradores de } \\
\text { produtos, tais como } \\
\text { anti-mofo, } \\
\text { conservantes, aditivos, } \\
\text { corantes, } \\
\text { emulsificantes. }\end{array}$ \\
\hline $\begin{array}{l}\text { Panelinha de } \\
\text { Coco }\end{array}$ & $\begin{array}{l}\text { Descrição: é um doce assado em forno, contendo uma massa fina externa e } \\
\text { recheio contendo obrigatoriamente coco ralado, açúcar e gemas de ovos. Tem } \\
\text { coloração amarelo tostado. Não possui decoração e é servido após o } \\
\text { resfriamento. Formato: seu formato é padrão, pois é assado em formas } \\
\text { específicas, que tem sua base de maior diâmetro que seu topo. } \\
\text { Sabor e textura: tem textura macia e sabor acentuado em coco. } \\
\text { Conservação: a temperatura ambiente (que não seja superior a } 25 \text { 0C) por no } \\
\text { máximo } 10 \text { dias. O prazo de validade deste doce é considerado enquanto se } \\
\text { mantiverem as características originais de sabor, apresentação, textura, cor e } \\
\text { principalmente ausência de desenvolvimento de contaminação microbiológica. } \\
\text { Aspectos nutricionais: por conter farinha de trigo este doce possui glúten. Este } \\
\text { doce não possui lactose, pois não utilizam-se leite ou seus derivados }\end{array}$ & $\begin{array}{l}\text { Proibições de } \\
\text { alterações da receita: } \\
\text { Não são aceitos } \\
\text { panelinhas recheadas } \\
\text { com outros tipos de } \\
\text { recheios. Não são } \\
\text { permitidos } \\
\text { melhoradores de } \\
\text { produtos, tais como } \\
\text { anti-mofo, } \\
\text { conservantes, aditivos, } \\
\text { corantes, } \\
\text { emulsificantes. } \\
\end{array}$ \\
\hline $\begin{array}{l}\text { Pastel de Santa } \\
\text { Clara }\end{array}$ & $\begin{array}{l}\text { Descrição: O pastel de Santa Clara é um doce feito de uma massa muito fina, } \\
\text { parecendo papel, dobrada em forma de um envelope com duas pontas que se } \\
\text { unem sobre o doce, é recheado com ovos moles. } \\
\text { Formato: formato retangular lembrando um envelope. } \\
\text { Sabor e textura: tem uma textura leve e crocante, partindo-se facilmente. O } \\
\text { sabor também é bastante suave. } \\
\text { Conservação: temperatura ambiente até } 7 \text { dias (que não seja superior a } 25 \text { OC), } \\
\text { ou enquanto mantém a crocância da massa. } \\
\text { Aspectos nutricionais: não possui lactose. Possui glúten. }\end{array}$ & $\begin{array}{l}\text { Proibições de } \\
\text { alterações da receita: } \\
\text { Não são permitidos os } \\
\text { melhoradores de } \\
\text { produtos, tais como } \\
\text { anti-mofo, } \\
\text { conservantes, aditivos, } \\
\text { corantes, } \\
\text { emulsificantes. }\end{array}$ \\
\hline
\end{tabular}


Patricia P. Peralta, Mônica Christina R. Morgado, Elizabeth F. Silva, Dirceu Y. Teruya

Continuação

\begin{tabular}{|c|c|c|}
\hline Produtos & Características & Restrições de Produção \\
\hline Queijadinha & $\begin{array}{l}\text { Descrição: doce similar ao quindim, diferindo-se por ter queijo parmesão ralado } \\
\text { em sua composição. É assado em forminhas metálicas padronizadas, em banho- } \\
\text { maria, decorado com uma uva passa preta ou um pedaço de ameixa seca preta. } \\
\text { Formato: seu formato é padrão, pois é assado em formas específicas, que tem sua } \\
\text { base de maior diâmetro que seu topo. } \\
\text { Sabor e textura: tem textura bastante macia, similar à textura de um pudim. O } \\
\text { sabor é acentuado em queijo e gemas. Conservação: A queijadinha pode ser } \\
\text { mantida a temperatura ambiente (que não seja superior a } 25 \text { 0C) por no máximo } \\
7 \text { dias. Para aumentar sua vida de prateleira pode ser mantido a temperatura de } \\
\text { refrigeração (de } 0 \text { OC a } 40 C \text { ) por no máximo } 10 \text { dias. O prazo de validade deste } \\
\text { doce é considerado enquanto se mantiverem as características originais de sabor, } \\
\text { apresentação, textura, cor e principalmente ausência de desenvolvimento de } \\
\text { contaminação microbiológica. } \\
\text { Aspectos nutricionais: este doce não pode conter glúten na sua composição, } \\
\text { porém pode conter traços deste, devido à forma artesanal de preparo e } \\
\text { possibilidade de contato com ingredientes que contenham glúten. Não pode } \\
\text { conter leite na receita. }\end{array}$ & $\begin{array}{l}\text { Proibições de } \\
\text { alterações da receita: } \\
\text { Não são permitidos os } \\
\text { melhoradores de } \\
\text { produtos, tais como } \\
\text { anti-mofo, } \\
\text { conservantes, aditivos, } \\
\text { corantes, } \\
\text { emulsificantes. }\end{array}$ \\
\hline Quindim & $\begin{array}{l}\text { Descrição: é um doce assado em forno, de massa homogênea contendo } \\
\text { obrigatoriamente coco ralado, açúcar e gemas de ovos. Tem coloração amarelada } \\
\text { em função de ser preparado com gemas de ovos e sabor acentuado de ovos e } \\
\text { coco. Não possui recheio, nem decoração, e é servido após o resfriamento em } \\
\text { forminhas de papel, chamadas pelotines e com fundo plástico chamado de fundo } \\
\text { rendado. } \\
\text { Formato: seu formato é padrão, pois é assado em formas específicas, que tem sua } \\
\text { base de maior diâmetro que seu topo. } \\
\text { Sabor e textura: tem textura bastante macia na parte da massa que não possui } \\
\text { coco, similar à textura de um pudim. Possui sabor acentuado de coco e gemas. } \\
\text { Conservação: o quindim pode ser mantido a temperatura ambiente (máximo } \\
25 \% \text { ) por no máximo } 7 \text { dias. Para aumentar sua vida de prateleira pode ser } \\
\text { mantido a temperatura de refrigeração (de } 0 \text { OC a } 40 C \text { ) por no máximo } 10 \text { dias. } \\
\text { O prazo de validade deste doce é considerado enquanto se mantiverem as } \\
\text { características originais de sabor, apresentação, textura, cor e principalmente } \\
\text { ausência de desenvolvimento de contaminação microbiológica. } \\
\text { Aspectos nutricionais: este doce não pode conter glúten na sua composição, } \\
\text { porém pode conter traços deste, devido à forma artesanal de preparo e } \\
\text { possibilidade de contato com ingredientes que contenham glúten. Pode conter } \\
\text { traços de clara de ovo. }\end{array}$ & $\begin{array}{l}\text { Proibições de } \\
\text { alterações da receita: } \\
\text { não se admitem } \\
\text { corantes ou qualquer } \\
\text { outro tipo de aditivo, } \\
\text { nem claras de ovos, } \\
\text { nem farinhas, nem } \\
\text { quaisquer outros } \\
\text { ingredientes que não } \\
\text { estejam identificados } \\
\text { no regulamento } \\
\text { técnico. }\end{array}$ \\
\hline $\begin{array}{l}\text { Trouxas de } \\
\text { Amêndoa }\end{array}$ & $\begin{array}{l}\text { Descrição: é similar ao ninho, porém é deitado, feito de placas ou fios de gemas } \\
\text { cozidas em calda e recheado com mistura de amêndoas e açúcar podendo conter } \\
\text { ovos moles ou não. } \\
\text { Formato: formato de cilindro deitado. Sabor e textura: é um doce de textura } \\
\text { macia com sabor predominantemente de ovos e amêndoas. } \\
\text { Conservação: indicada refrigeração de no máximo } 40 C \text { por no máximo } 7 \text { dias. O } \\
\text { prazo de validade deste doce é considerado enquanto se mantiverem as } \\
\text { características originais de sabor, apresentação, textura, cor e principalmente } \\
\text { ausência de desenvolvimento de contaminação microbiológica. } \\
\text { Aspectos nutricionais: este doce não pode conter glúten na sua composição, } \\
\text { porém pode conter traços deste, devido à forma artesanal de preparo e } \\
\text { possibilidade de contato com ingredientes que contenham glúten. Pode conter } \\
\text { traços de clara de ovo }\end{array}$ & $\begin{array}{l}\text { Proibições de } \\
\text { alterações da receita: } \\
\text { Não são permitidos os } \\
\text { melhoradores de } \\
\text { produtos, tais como } \\
\text { anti-mofo, } \\
\text { conservantes, aditivos, } \\
\text { corantes, } \\
\text { emulsificantes. }\end{array}$ \\
\hline
\end{tabular}

Fonte: Associação dos Produtores de Doces de Pelotas.

O processo de reconhecimento da indicação de procedência para os doces de Pelotas promoveu uma padronização da produção dos doces entre os associados. Entre as contribuições, destacam-se a possibilidade de ter acesso à informação, a cursos, bem como às divulgações e às orientações sobre o próprio negócio. Como 
limitações, surgiram questões como a dificuldade de aceitação de ideias inovadoras, no que tange à confecção dos produtos, dadas as exigências referentes à padronização do tamanho do doce, o modus operandi de fabricação e as restrições de ingredientes dos doces, conforme o quadro 1.

Diante disso, há um agrupamento de produtores de doces atuantes na região de Pelotas que apresentaram dificuldades em se adequar às propostas da IP devido à cultura organizacional, haja vista a informalidade que vivenciam (MARCHI et al, 2009).

\section{Considerações finais}

O setor agroalimentar é relevante economicamente para o Brasil, pois gera emprego, renda e oportunidades de negócios. A dinâmica do setor agroalimentar, no Brasil, tem-se alterado ao longo dos últimos 40 anos, como reflexo do cenário internacional e da internacionalização das cadeias produtivas agroindustriais.

A competitividade desse setor é baseada em custos de produção e de distribuição, por isso o processo inovativo está voltado para a promoção de produtos agrícolas e agroindustriais a preços competitivos no mercado internacional. Esse processo de competição é somente realizado por grandes conglomerados por conta da necessidade de elevados investimentos produtivos, necessidade de economias de escala e de escopo e a constituição de canais de distribuição para os produtos agrícolas e agroindustriais.

Ao mesmo tempo, existe a necessidade de implementar mecanismos de diferenciação de produtos agrícolas e agroindustriais, uma vez que esses produtos são caracterizados como commodities. Nesse sentido, a indicação geográfica pode contribuir para organizar os agentes locais e promover o modelo de negócio em termos regionais.

Entretanto, a IG não se traduz em condição suficiente para promover a diferenciação do produto. Embora se revele instrumento potencializador quando associada a outros instrumentos decorrentes do modelo de negócio e da estrutura de governança dos agentes envolvidos.

A organização da Associação dos Produtores de Doces de Pelotas tem sido importante na governança dos associados, (e dos demais participantes da cadeia produtiva de doces).

Apesar de terem obtido o reconhecimento da indicação de procedência pelo INPI, as sociedades empresárias participantes da Associação têm dificuldades de explorar o potencial do instrumento. Essa situação pode decorrer da limitação da concepção do modelo de negócio, relacionado aos doces de confeitaria e frutas, bem como da existência dos concorrentes que apresentem escala de produção e os concorrentes informais, que inserem os doces no mercado a um preço relativamente menor.

Como são pequenos produtores, as economias de escala e de escopo são restritas, dada a capacidade de produção, bem como a de exportação dos doces para regiões distantes devido à fragilidade do produto. 
Por fim, cabe ressaltar o campo crescente, porém ainda incipiente, dos estudos relacionados às IGs no Brasil. Este artigo vem somar-se a esse conjunto de produções acadêmicas que vêm ganhando espaço, com o objetivo de ser um contributo para formas diferenciadas de olhar para os potenciais das IGs. Além disso, destaca-se, neste trabalho, a riqueza de documentação presente nos processos de IGs depositados junto ao INPI, que podem constituir-se em objetos de pesquisa para futuros trabalhos. Correlacionar essa documentação com outras de campos diversos poderá possibilitar trabalhos interdisciplinares que ajudem a compreender e a implementar políticas públicas e institucionais, visando a tornar o reconhecimento de uma IG em algo capaz de desenvolver a localidade e aportar vantagens para os produtores.

Faz-se premente ampliar o campo de pesquisa sobre IGs em função do potencial que esse instrumento de proteção possui no comércio internacional. Dessa forma, esta pesquisa, além de apontar para a possibilidade de estudos da documentação apresentada ao INPI, objetiva incentivar e disseminar a temática referente às IGs em outros fora de debate e discussão, visando à construção de redes ampliadas acerca do conhecimento das IGs.

\section{REFERÊNCIAS}

ALLAIRE, Gilles. "A contribuição da sociologia econômica para compreender o significado da qualidade nos mercados alimentares". In.: NIERDELE, Paulo André. Indicações geográficas: qualidade e origem nos mercados alimentares. Porto Alegre: Editora da UFRGS, p. 55-80, 2013.

BELLETTI, Giovanni, MARESCOTTI, Andrea, SANZ-CAÑADA, Javier, VAKOUFARIS, Hristos. Linking protection of geographical indications to the environment: Evidence from the European Union olive-oil sector. Land Use Policy vol. 48, p. 94-106, $2015 \mathrm{a}$. BELLETTI, Giovanni, MARESCOTTI, Andrea, Touzard, J.M.,. Geographical Indications, Public Goods and Sustainable Development: the roles of actors' strategies and public policies. World Development (no prelo), 2015b.

CASABIANCA, François; SYLVANDER, BERTIL; NOËL, YOLANDE; BÉRANGER, CLAUDE; COULON, JEAN-BAPTISTE; RONCIN, FRANÇOIS; FLUTET, GILLES; GIRAUD, GEORGES. "Terroir e tipicidade: dois conceitos-chave para as indicações geográficas. In.: NIERDELE, Paulo André. Indicações geográficas: qualidade e origem nos mercados alimentares. Porto Alegre: Editora da UFRGS, 2013, p. 201-226.

CERDAN, Claire. "Indicações geográficas e estratégias de desenvolvimento territorial". In.: NIERDELE, Paulo André. Indicações geográficas: qualidade e origem nos mercados alimentares. Porto Alegre: Editora da UFRGS, p. 125-150, 2013. 
FARINA, ELIZABETH Q. M, ZYLBERSZTAJN DECIO. Relações tecnológicas e organização dos mercados do sistema agroindustrial de alimentos. Cadernos de Ciência \& Tecnologia, vol. 8, no. 1/3: p. 9-27, 1991.

FERREIRA, Maria L. Mazzucchi CERQUEIRA, Fábio Vergara; RIETH, Flávia Maria da Silva. O doce pelotense como patrimônio imaterial: diálogos entre o tradicional e a inovação MÉTIS: história \& cultura,.p. 91-113, 200

GONÇALVES, M.F.W. Propriedade industrial e a proteção dos nomes geográficos: indicações geográficas, indicações de procedência e denominações de origem. Curitiba: Juruá, 2007.

LENGLER, Leticia; CORONEL, D. A; LAGO, A.; SILVA, T. N. Fruticultura e atividade doceira como alternativas de desenvolvimento para o município de Pelotas/RS/Brasil. Sociais e Humanas, v. 1, p. 77-88, 2008.

MARQUES KNEIPP, Jordana; MARCHI, Jamur Johnas; MAFFINI GOMES, Clandia; BARBIERI DA ROSA, Luciana Aparecida. Proposições estratégicas a partir da análise da rede de valor e do capital social: um estudo no polo de doces de Pelotas - RS, Revista de Ciências da Administração, vol. 15, núm. 36, mayo-agosto, pp. 175-192, 2013,.

MARCHI, Jamur Johnas; PATIAS, Tiago Zardin; KNEIPP, Jordana Marques, O pólo de doces de Pelotas-Rs sob a perspectiva da rede de valor: possibilidades estratégicas In Anais do XXIX Encontro Nacional de Engenharia de Produção: a Engenharia de Produção e o Desenvolvimento Sustentável: Integrando Tecnologia e Gestão. Salvador, 2009.

NIERDELE, Paulo André. " " In.: NIERDELE, Paulo André. Indicações geográficas: qualidade e origem nos mercados alimentares. Porto Alegre: Editora da UFRGS, 2013. NIERDELE, Paulo André.. Compromissos para a qualidade: projetos de indicação geográfica para vinhos no Brasil e na França. Tese de Doutorado, Universidade Federal Rural do Rio de Janeiro, Rio de Janeiro, 2011.

QUIÑONES-Ruiz, Xiomara F., PENKER, Marianne, BELLETTI, Giovanni, MARESCOTTI, Andrea, SCARAMUZZI, Silvia. Why early collective action pays off: evidence from setting Protected Geographical Indications. Renewable Agriculture and Food Systems, p.1-14, 2016.

TONIETTO, J. Afinal, o que é Terroir? Bon Vivant, Flores da Cunha, v. 8, n. 98, p. 08, abr. 2007.

VITROLLES, Delphine. "A valorização de produtos de origem no Brasil: um comparativo entre mecanismos de qualificação". In.: NIERDELE, Paulo André. 
Indicações geográficas: qualidade e origem nos mercados alimentares. Porto Alegre: Editora da UFRGS, p. 151-178, 2013.

WILKINSON, John, Mercosul e globalização: novos padrões de concorrência agroalimentar, Estudos Sociedade e Agricultura, Rio de Janeiro, vol. 7, pp. 90-112, 1996.

- A agricultura familiar ante o novo padrão de competitividade do sistema agroalimentar na América Latina, Estudos Sociedade e Agricultura, Rio de Janeiro, vol. 21, pp. 62-87, 2003.

Submetido em 02/09/2014

Aprovado em 27/06/2016

\section{Sobre os Autores}

Patricia Pereira Peralta

Pós-doutorado em Estudos Culturais pelo Programa Avançado de Cultura Contemporânea - UFRJ. Doutora em Artes Visuais pela UFRJ. Docente permanente do Mestrado Profissional do INPI e docente colaboradora do Mestrado Profissional do Instituto do Patrimônio Histórico e Artístico - IPHAN.

E-mail: ppereira@inpi.gov.br

\section{Mônica Christina Rodrigues Morgado}

Mestre em Direito pela Universidade de Lisboa. Tecnologista em Propriedade Industrial do Instituto Nacional da Propriedade Industrial.

E-mail: monica@inpi.gov.br

\section{Elizabeth Ferreira da Silva}

Doutora em Engenharia Civil pela Universidade Federal do Rio de Janeiro. Pesquisadora do Instituto Nacional da Propriedade Industrial - INPI. Docente do Programa de Mestrado Profissional em Propriedade Intelectual e Inovação e do Doutourado Acadêmico em Propriedade Intelectual e Inovação, ambos do INPI.

E-mail: silvaef@inpi.gov.br

\section{Dirceu Yoshikazu Teruya}

Doutor em Integração da América Latina pela Universidade de São Paulo. Pesquisador em Propriedade Industrial do Instituto Nacional da Propriedade Industrial. Docente do Programa de Pós-Graduação em Propriedade Intelectual e Inovação do Instituto Nacional da Propriedade Industrial e tutor do Curso Geral à Distância em Propriedade Intelectual, ambos do INPI.

E-mail: teruya@inpi.gov.br 